\title{
ॠUSGS \\ semamsang
}

\section{Hydraulic Property and Soil Textural Classification Measurements for Rainier Mesa, Nevada Test Site, Nevada}

By Brian A. Ebel and John R. Nimmo
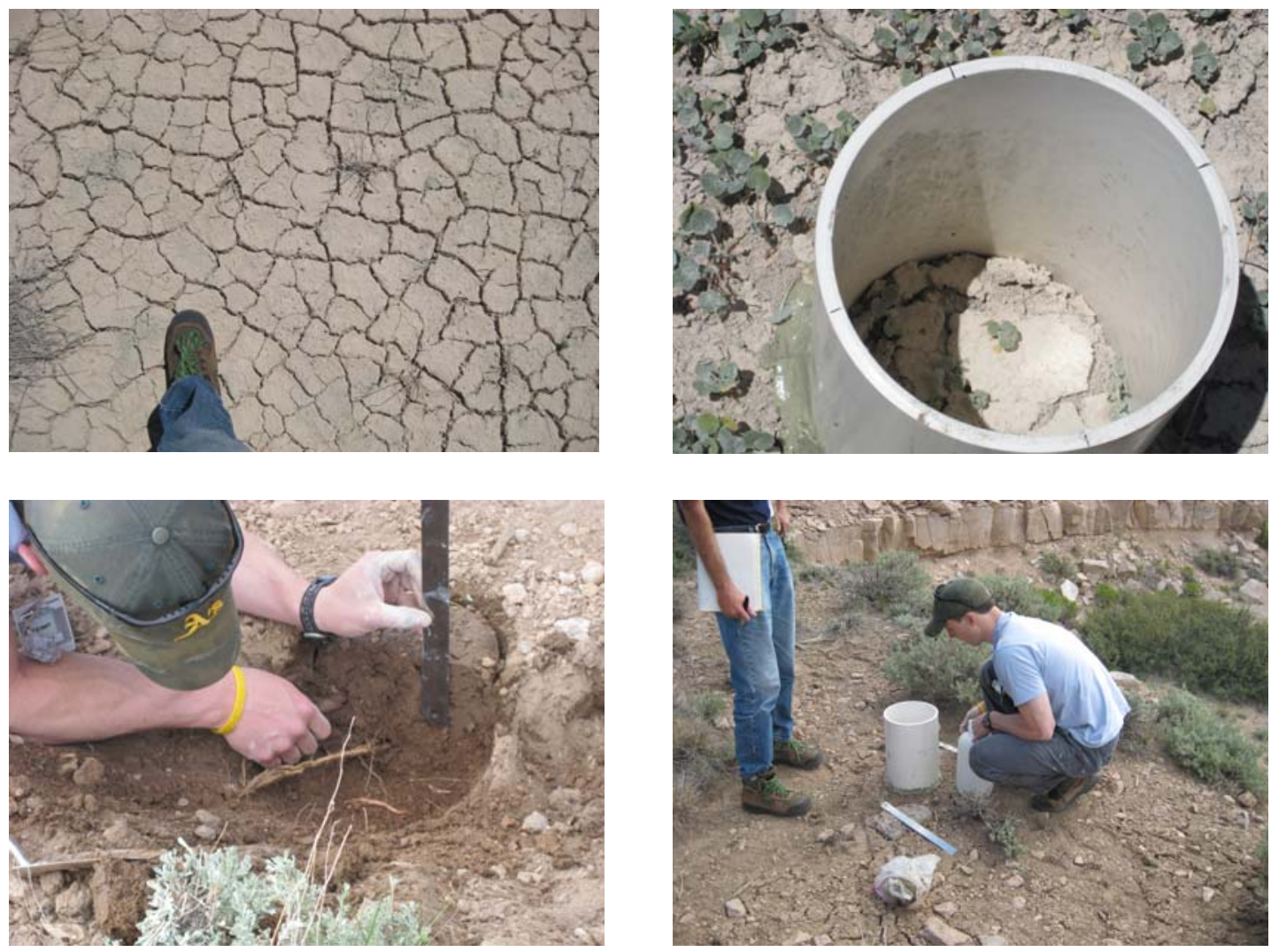

Prepared in cooperation with the U.S. Department of Energy, National Nuclear Security Administration, Nevada Site Office under Interagency Agreement DE-AI52-07NV28100

Open-File Report 2009-1264 


\section{U.S. Department of the Interior \\ KEN SALAZAR, Secretary}

\section{U.S. Geological Survey \\ Marcia K. McNutt, Director}

U.S. Geological Survey, Reston, Virginia: 2010

For product and ordering information:

World Wide Web: http://www.usgs.gov/pubprod

Telephone: 1-888-ASK-USGS

For more information on the USGS-the Federal source for science about the Earth, its natural and living resources, natural hazards, and the environment:

World Wide Web: http://www.usgs.gov

Telephone: 1-888-ASK-USGS

Suggested citation:

Ebel, B.A., and Nimmo, J.R., 2010, Hydraulic property and soil textural classification measurements for Rainier Mesa, Nevada Test Site, Nevada: U.S. Geological Survey Open-File Report 2009-1264, 17 p.

[http://pubs.usgs.gov/of/2009/1264/].

Any use of trade, product, or firm names is for descriptive purposes only and does not imply endorsement by the U.S. Government.

Although this report is in the public domain, permission must be secured from the individual copyright owners to reproduce any copyrighted material contained within this report

Front cover (clockwise, from upper left): (1) Surface cracks in U12n tunnel pond sediments, June, 2008. (2) A "bottomless bucket" installed in U12n tunnel pond sediments, June, 2008. (3) Estimating field-saturated hydraulic conductivity on top of Rainier Mesa, June, 2008. (4) Measuring penetration depth of infiltrating water on top of Rainier Mesa, June, 2008. 


\section{Contents}

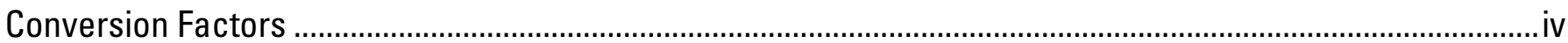

Abstract

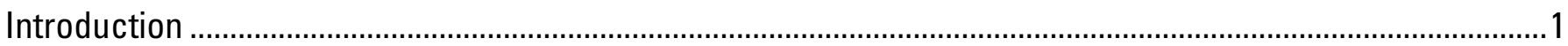

Measurements and Samples Collected ………………….........................................................................

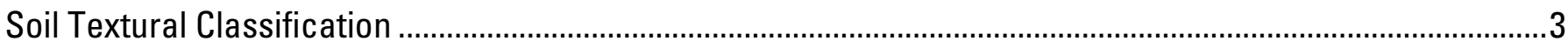

Field-Saturated Hydraulic Conductivity Estimation ..................................................................................

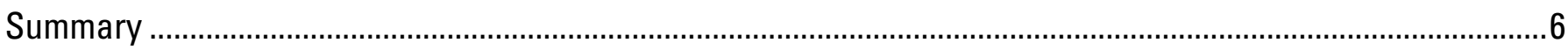

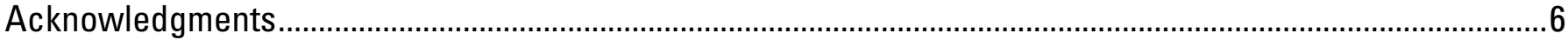

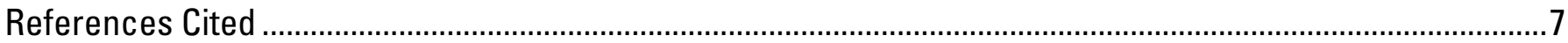

\section{Figures}

Figure 1. Map of the NTS showing the location of Rainier Mesa.................................................................12

Figure 2. Shaded relief map of Rainier Mesa showing the locations of infiltration tests and soil samples. Image from the National Map Seamless Server of the USGS.

Figure 3. Satellite images of the U12n tunnel portal area and ponds at Rainier Mesa showing infiltration test locations.

Figure 4. Photographs of measurement sites (A) RM1 (B) RM2 (C) RM4 and RM5 (D) RM6

(E) NT1 and NT2 (F) NT3.

Figure 5. Probability distribution functions given in percentages based on particle size analysis of the six soil samples from Rainier Mesa.

Figure 6. Cumulative distribution functions given in cumulative percentages based on particle size analysis of the six soil samples from Rainier Mesa.

\section{Tables}

Table 1. Particle size analysis statistics from Rainier Mesa soil samples using the method of moments, presented in Beyer (1991)..

Table 2. USDA textural class information from particle size analysis of Rainier Mesa soil samples.........9

Table 3. Cumulative frequency distribution statistics, by diameter, from particle size analysis of Rainier Mesa soil samples.

Table 4. Ponded $K_{f s}$ estimates from Rainier Mesa using the Nimmo and others (2009) method.. 


\section{Conversion Factors}

SI to Inch/Pound

\begin{tabular}{lcl}
\hline \multicolumn{1}{c}{ Multiply } & \multicolumn{1}{c}{ By } & \multicolumn{1}{c}{ To obtain } \\
\hline Length & & \\
\hline centimeter $(\mathrm{cm})$ & 0.3937 & inch (in.) \\
meter $(\mathrm{m})$ & 3.281 & foot $(\mathrm{ft})$ \\
Kilometer $(\mathrm{km})$ & 0.6214 & mile $(\mathrm{mi})$ \\
Liter $(\mathrm{L})$ & 0.2642 & Gallon $(\mathrm{gal})$ \\
cubic meter $\left(\mathrm{m}^{3}\right)$ & 264.2 & Gallon $(\mathrm{gal})$ \\
Liter $(\mathrm{L})$ & 61.02 & Cubic inch $\left(\mathrm{in}{ }^{3}\right)$ \\
\hline Flow rate & & \\
\hline meter per second $(\mathrm{m} / \mathrm{s})$ & 3.281 & foot per second $(\mathrm{ft} / \mathrm{s})$ \\
meter per day $(\mathrm{m} / \mathrm{d})$ & 3.281 & foot per day $(\mathrm{ft} / \mathrm{d})$ \\
\hline
\end{tabular}

Vertical coordinate information is referenced to North American Vertical Datum of 1988 (NAVD 88). Horizontal coordinate information is referenced to the North American Datum of 1983 (NAD 83). Altitude, as used in this report, refers to distance above the vertical datum. 


\title{
Hydraulic Property and Soil Textural Classification Measurements for Rainier Mesa, Nevada Test Site, Nevada
}

\author{
By Brian A. Ebel and John R. Nimmo
}

\begin{abstract}
This report presents particle size analysis, field-saturated hydraulic conductivity measurements, and qualitative descriptions of surficial materials at selected locations at Rainier Mesa, Nevada. Measurements and sample collection were conducted in the Rainier Mesa area, including unconsolidated sediments on top of the mesa, an ephemeral wash channel near the mesa edge, and dry U12n tunnel pond sediments below the mesa. Particle size analysis used a combination of sieving and optical diffraction techniques. Field-saturated hydraulic conductivity measurements employed a single-ring infiltrometer with analytical formulas that correct for falling head and spreading outside the ring domain. These measurements may prove useful to current and future efforts at Rainier Mesa aimed at understanding infiltration and its effect on water fluxes and radionuclide transport in the unsaturated zone.
\end{abstract}

\section{Introduction}

Underground nuclear testing was conducted at Rainier Mesa within the Nevada Test Site in Nye County, Nev. (see fig. 1), with a total of 61 tests between 1957-1992 (Department of Energy, 2000). All the underground nuclear tests at this site, with the exception of two vertical borehole tests, took place within mined tunnels (National Security Technologies, 2007). The Rainier Mesa-Shoshone Mountain Corrective Action Unit (CAU) (National Nuclear Security Administration, 2004) is of interest to the U.S. Department of Energy and certain regulatory agencies at the State and Federal level owing to the potential for radionuclide transport to the saturated zone (Fenelon and others, 2008). The entry of water into the subsurface is a critical part of the conceptual model needed to understand water movement through the thick unsaturated zone that overlies the saturated zone at this site. This report summarizes preliminary investigations at Rainier Mesa designed to get a basic understanding of physical and hydraulic properties of soil and unconsolidated sediments that may control infiltration. These measurements are far from comprehensive owing to restrictions of time, cost, and site access; but in the absence of other hydraulic property estimates they may inform ongoing and future efforts aimed at understanding radionuclide fate and transport in the unsaturated and saturated zones at Rainier Mesa. Further descriptions of Rainier Mesa can be found in Thordarson (1965), Russell (1987), Russell and others (2001), and Ebel and Nimmo (2009). 


\section{Measurements and Samples Collected}

The locations of measurements and samples collected at the site are show in figure 2 for RM1, RM2, RM4, RM5, and RM6 and in figure 3 for RM NT1, RM NT2, and RM NT3. Each sample/measurement is described briefly below and photographs of sample locations are shown in figure 4 :

\section{$\underline{\operatorname{RM} 1(6 / 2 / 2008)}$ :}

Sample location RM1 is approximately $5 \mathrm{~m}$ from the edge of a small rock cliff atop Rainier Mesa (fig. $4 A$ ). The soil is stony with some desiccation cracks. Excavation revealed a soil textural boundary at $8 \mathrm{~cm}$ depth, with fine-textured soil overlying a coarser-textured soil. Soil grab samples for particle size analysis were taken at 4 and $14 \mathrm{~cm}$ depth. An infiltration test was conducted at this location.

$\underline{\operatorname{RM} 2(6 / 2 / 2008):}$

Sample location RM2 is approximately $2 \mathrm{~m}$ from the edge of a small rock cliff atop Rainier Mesa (fig. $4 B$ ). A soil textural boundary is present at $10 \mathrm{~cm}$ depth, with fine-textured soil overlying a coarser-textured, more-stony soil. Soil grab samples for particle size analysis were taken at 4 and $12 \mathrm{~cm}$ depth. An infiltration test was conducted at this location.

\section{RM4 (6/2/2008):}

Sample location RM4 is beneath a Juniper tree atop Rainier Mesa (fig. 4C). The soil surface is covered with Juniper needles and duff with an organic horizon for the first $5 \mathrm{~cm}$ below the surface, transitioning into a fine-textured soil that grades into a progressively finer-textured soil below $15 \mathrm{~cm}$ depth. A few large stones are present, up to $15 \mathrm{~cm}$ diameter. Soil grab samples for particle size analysis were taken at 10 and $19 \mathrm{~cm}$ depth. An infiltration test was conducted at this location.

\section{RM5 (6/2/2008):}

The same location at RM4, but infiltration testing was repeated.

\section{RM6 (6/2/2008):}

Sample location RM6 is located in a wash atop Rainier Mesa near the main access road (fig. 4D). The sediments in the wash are sands and fine to coarse gravels. Excavation was not conducted and grab samples were not taken. An infiltration test was conducted at this location.

\section{RM NT1 (6/3/2008):}

Sample location RM NT1 is within the U12n tunnel pond N3 (dry), at the downgradient end near the edge of the pond bed (fig. 4E). Sediment/soil in the pond bottom is fine-textured with abundant surface cracking. A hard, dry soil layer that appears clayey is present at approximately $9 \mathrm{~cm}$ depth. Soil grab samples for particle size analysis were not taken. An infiltration test was conducted at this location. 
$\underline{\operatorname{RM} N 2(6 / 3 / 2008)}$ :

The same location at RM NT1, but infiltration testing was repeated.

$\underline{\operatorname{RM} N T 3(6 / 3 / 2008)}$ :

Sample location RM NT3 is within the U12n tunnel pond N3 (dry) at the upgradient end (fig. 4F). Sediment/soil in the pond bottom is similar to RM NT1. Excavation revealed a fine-textured soil in the top $7 \mathrm{~cm}$. From 7-10 cm depth, the soil transitions into coarser-textured material. Soil grab samples for particle size analysis were not taken. An infiltration test was conducted at this location.

\section{Soil Textural Classification}

The soil samples from Rainier Mesa were analyzed using a combination of sieving and optical diffraction. Particles greater than $2 \mathrm{~mm}$ in diameter were passed through standard American Society for Testing and Materials (ASTM) sieves (sizes 2, 2.8, 4, 5.6, 8, 11.2, 16, 22.4, and $32.5 \mathrm{~mm}$ ) to separate those particle size ranges. The remaining part of the sample (that is, the part less than $2 \mathrm{~mm}$ in diameter) was physically disaggregated using a ceramic mortar and rubber-coated pestle. The disaggregated material was then split into representative samples for optical diffraction using a Gilson 16-part rotary sample divider. The divided samples of particle diameters less than $2 \mathrm{~mm}$ were analyzed using a Coulter LS-230 optical diffraction apparatus (Gee and Or, 2002), which is capable of measuring particle sizes from $4 \times 10^{-5}$ to $2 \mathrm{~mm}$ diameter. Sonication of samples when suspended in water during the sample run facilitates further disaggregation. The Fraunhofer diffraction model is employed to estimate the particle size distribution from the optical diffraction pattern, assuming spherical particles. The analysis is divided into histogram bins based on the particle diameters on a logarithmic scale (see Winfield, 2003). The geometric mean particle diameter $\left(M_{g}\right)$ and geometric particle size standard deviation $\left(\sigma_{g}\right)$ for each sample distribution is estimated using the method of moments, presented in Beyer (1991). The formula for $M_{g}$ is:

$$
\log \left(M_{g}\right)=\frac{\sum\left[f\left(d_{c}\right) \log \left(d_{c}\right)\right]}{\sum\left[f\left(d_{c}\right)\right]}
$$

where $d_{c}$ is the geometric center of each histogram bin and $f\left(d_{c}\right)$ is the frequency of sizes occurring within the given histogram associated with $d_{c}$. The formula for $\sigma_{g}$ is:

$$
\left[\log \left(\sigma_{g}\right)\right]^{2}=\frac{\sum\left\{f\left(d_{c}\right)\left[\log \left(d_{c}\right)-\log \left(M_{g}\right)\right]^{2}\right\}}{\sum\left[f\left(d_{c}\right)\right]}
$$

The final particle size distribution of the sample is the mean of the triplicate subsample runs.

Table 1 shows the arithmetic and geometric mean particle diameters and standard deviations for the six soil/sediment samples from Rainier Mesa. Table 2 contains the textural class information based on the U.S. 
Department of Agriculture (USDA) system, and table 3 has the cumulative frequency distribution statistics summarized by particle diameter. Figure 5 shows the probability distribution functions of particle sizes for the Rainier Mesa soil samples. Figure 6 shows the cumulative distribution functions of particle sizes for the Rainier Mesa soil samples.

\section{Field-Saturated Hydraulic Conductivity Estimation}

When water is supplied at the land surface at a rate sufficient to cause ponding, the hydraulic conductivity can reach a value known as the field-saturated hydraulic conductivity $\left(K_{f_{s}}\right)$. This value is less than the fully saturated hydraulic conductivity $\left(K_{s}\right)$ that one might attain in a laboratory setting owing to the presence of entrapped air that blocks conductive pores. The estimates of $K_{f s}$ are typically dominated by the most conductive pathways, such as macropores. As noted by Nimmo and others (2009) this implies that tests at the same location at different times may have different $K_{f s}$ values because different pores may be air-obstructed during a given test. A single-ring infiltrometer method was used to estimate $K_{f s}$ at the locations described previously at Rainier Mesa using the methodology described by Nimmo and others (2009) for falling-head, small-diameter ( $20 \mathrm{~cm})$ single-ring infiltrometers. The technique employs a formulation that accounts for subsurface spreading for smaller infiltration rings and falling ponded hydraulic heads. The technique is called a "bottomless bucket" in this report, a section of $21.1 \mathrm{~cm}$ inner diameter Schedule 40 PVC pipe serves as the infiltration ring. What is measured in the falling-head test is infiltration flux density $(i) . K_{f s}$ can be assumed to deviate systematically from $i$, where $i$ is greater than $K_{f s}$ by a factor $F$ such that:

$$
K_{f s}=\frac{i}{F}
$$

where $F$ accounts for sorption and lateral spreading effects. Using the formula proposed by Reynolds and Elrick (1990), $K_{f s}$ can be estimated as:

$$
K_{f s}=\frac{i}{\left[1+\frac{\lambda+D}{L_{G}}\right]}
$$

where $\lambda$ is as the macroscopic capillary length of the soil (see White and Sully, 1987), $D$ is the ponded depth inside the ring, and $L G$ is the ring-installation scaling length. $L G$ can be approximated using the relation:

$$
L_{G}=C_{1} d+C_{2} b
$$

where $C_{1}$ and $C_{2}$ are empirically determined constants with values of 0.993 and 0.578 , respectively (see Reynolds and Elrick, 1990), $d$ is the ring insertion depth, and $b$ is the ring radius. The infiltration test must be completed in soil which is initially dry so that $K_{f s}$ is much larger than the unsaturated hydraulic conductivity at the initial 
condition. The condition of falling head during the infiltration test requires modification to equation (5), such that $K_{f s}$ can be estimated using:

$$
K_{f s}=\frac{-\frac{d D}{d t}}{\frac{1}{L_{G}}\left[L_{G}+\lambda+D\right]}
$$

Equation (6) can be rearranged, integrated over time $(t)$ that is the elapsed time of the head falling from the initial ponded depth value $\left(D_{0}\right)$ to the ponded depth value at a given time $[D(t)]$ (see Nimmo and others, 2009) to give:

$$
K_{f s}=\frac{L_{G}}{t} \ln \left(\frac{L_{G}+\lambda+D_{o}}{L_{G}+\lambda+D}\right)
$$

The bottomless bucket tests provide a set of $D$ values over time for a given test location and equation (7) can be rearranged to form a linear algebraic equation given by:

$$
L_{G} \ln \left(\frac{L_{G}+\lambda+D_{o}}{L_{G}+\lambda+D}\right)=K_{f s} t,
$$

such that the slope of the line of the left-hand side of equation (7) versus $t$ provides $K_{f s}$. Excavation of soil/sediment beneath each infiltration test site is described below (if excavation was conducted), and the $K_{f s}$ results are shown in table 4. The value for $b$ is $10.1 \mathrm{~cm}$ and the value for $d$ is measured for each test. The $\lambda$ value is chosen on the basis of the approximate soil textural classification for a given site, as recommended by Elrick and others (1989).

The $\lambda$ values, proposed by Elrick and others (1989), used in this work are $0.08 \mathrm{~m}$ for most soils, $0.03 \mathrm{~m}$ for very coarse-textured soils, and $0.25 \mathrm{~m}$ for fine-textured soils without preferential flow paths. Nimmo and others (2009) found that the estimated $K_{f s}$ values were minimally sensitive to the chosen $\lambda$.

Notes for each bottomless bucket test are summarized below and photographs of measurement locations are shown in figure 4 :

RM1 (6/2/2008):

Excavation of soil below the bottomless bucket test revealed very little lateral spreading at depth (location photograph shown in fig. $4 A$ ).

RM2 (6/2/2008):

No excavation conducted beneath bottomless bucket test (location photograph shown in fig. $4 B$ ).

RM4 (6/2/2008):

Excavation of soil below the bottomless bucket test showed much visual evidence of preferential flow in irregular patterns with sharply defined wetted-edges, likely to be fingered flow (location photograph shown in fig. $4 C$ ). 
RM5 (6/2/2008):

See excavation results for RM4.

RM6 (6/2/2008):

Excavation of wash sediments below the bottomless bucket test showed mostly vertical flow with little spreading (location photograph shown in fig. $4 D$ ).

$\underline{\operatorname{RMNT1}(6 / 3 / 2008):}$

Excavation of soil below the bottomless bucket test showed lateral speading at $2 \mathrm{~cm}$ depth at the approximate termination of desiccation cracking. Water from the infiltration test appeared to stop at the clayey layer at $9 \mathrm{~cm}$ depth. No soil sample taken (location photograph shown in fig. 4E).

\section{$\underline{\operatorname{RM} N T 2(6 / 3 / 2008):}$}

See excavation results for RM NT1. No soil sample taken.

RM NT3 (6/3/2008):

Excavation of soil below the bottomless bucket test showed $10 \mathrm{~cm}$ of water penetration, with the fine-grained surficial material in the top $3 \mathrm{~cm}$ becoming field saturated and the soil between 4 and $7 \mathrm{~cm}$ being nearly saturated. No soil sample taken (location photograph shown in fig. $4 F$ ).

\section{Summary}

Tables 1 through 4 and figures 5 and 6 show that most of the particle size distributions for the samples from the top of Rainier Mesa (RM1, RM2, and RM4) have multimodal distributions with a peak slightly smaller than $0.1 \mathrm{~mm}$ and one or more peaks at particle sizes near or greater than $10 \mathrm{~mm}$. The RM4 sample at $10 \mathrm{~cm}$ has one main peak at particle sizes slightly less than $0.1 \mathrm{~mm}$. The deeper samples generally have larger mean particles size diameters, larger standard deviations, and less fine particles (except for the RM4 sample at $19 \mathrm{~cm}$ ). The comparison between the particle size distributions and $K_{f s}$ values suggests that the top several centimeters of soil has a significant influence on $K_{f s}$ at Rainier Mesa and that the presence of fine particles at RM1 and RM2 may cause the $K_{f s}$ to be smaller relative to RM4. Care should be exercised when generalizing the site-specific results presented here into a broader context of the patterns and heterogeneity of particle size distributions and $K_{f s}$ values for Rainier Mesa. A more comprehensive study would be necessary before such generalization could be prudently attempted.

\section{Acknowledgments}

The work presented here benefitted from the thoughtful comments of Kim Perkins and Marjorie Schulz. Prepared in cooperation with the U.S. Department of Energy, National Nuclear Security Administration, Nevada Site Office under Interagency Agreement DE-AI52-07NV28100. 


\section{References Cited}

Beyer, W.H., ed., 1991, CRC Standard Mathematical Tables and Formulae (29th ed.): CRC Press, Inc., Boca Raton, Florida, 609 p.

Department of Energy, 2000, United States Nuclear Tests July 1945 through September 1992: U.S. Department of Energy Report DOE/NV--209-REV 15, 185 p.

Ebel, B.A., and Nimmo, J.R., 2009, Estimation of unsaturated zone travel times for Rainier Mesa and Shoshone Mountain, Nevada Test Site, Nevada using a source-responsive preferential-flow model: U.S. Geological Survey Open-File Report 2009-1175, 74 p. [http://pubs.usgs.gov/of/2009/1175/].

Elrick, D.E., Reynolds, W.D., and Tan, K.A., 1989, Hydraulic conductivity measurements in the unsaturated zone using improved well analyses: Ground Water Monitoring Review, v. 9, p. 184-193.

Fenelon, J.M., Laczniak, R.J., and Halford, K.J., 2008, Predevelopment water-level contours for aquifers in the Rainier Mesa and Shoshone Mountain area of the Nevada Test Site, Nye County, Nevada: U.S. Geological Survey Scientific Investigations Report 2008-5044, 38 p. [http://pubs.usgs.gov/sir/2008/5044/].

Gee G.W., and Or, D., 2002, Particle size analysis, in Dane, J.H., and Topp, G.C., ed., Methods of soil analysis, Part 4-Physical methods, Soil Science Society of America Book Series No. 5, Madison, Wisconsin, p. 255-293.

National Nuclear Security Administration, 2004, Corrective action investigation plan for corrective action unit 99: Rainier Mesa/Shoshone Mountain, Nevada Test Site, Nevada: U.S. Department of Energy Report DOE/NV--1031, revision no. $0,320 \mathrm{p}$.

National Security Technologies, LLC, 2007, A hydrostratigraphic model and alternatives for the groundwater flow and contaminant transport model of corrective action unit 99-Rainier Mesa-Shoshone Mountain, Nye County, Nevada: U.S. Department of Energy Report DOE/NV/25946--146, 302 p.

Nimmo, J.R., Schmidt, K.M., Perkins, K.S. and Stock, J.D., 2009, Rapid measurement of field-saturated hydraulic conductivity for areal characterization: Vadose Zone Journal, v. 8, p. 142-149, doi:10.2136/vzj2007.0159.

Reynolds, W.D., and Elrick, D.E., 1990, Ponded infiltration from a single ring; I, Analysis of steady flow: Soil Science Society of America Journal, v. 54, p. 1233-1241

Russell, C.E., 1987, Hydrogeologic investigations of flow in fractured tuffs, Rainier Mesa, Nevada Test Site: Las Vegas, Nev., University of Nevada, M.S. thesis, 154 p.

Russell, C.E., Hess, J.W., and Tyler, S.W., 2001, Hydrogeologic investigations of flow in fractured tuffs, Rainier Mesa, Nevada Test Site, in Evans, D.D., Nicholson, T.J., and Rasmussen, T.C., eds., Flow and transport through unsaturated fractured rock: Washington, D.C., American Geophysical Union, Geophysical Monograph 42, p. 105112.

Thordarson, W., 1965, Perched groundwater in zeolitized-bedded tuff, Rainier Mesa and vicinity, Nevada Test Site, Nevada: U.S. Geological Survey Open-File Report 66-130, 94 p. [http://pubs.er.usgs.gov/usgspubs/ofr/ofr66130].

White, I., and Sully, M.J., 1987, Macroscopic and microscopic capillary length and time scales from field infiltration: Water Resources Research, v. 23, p. 1514-1522.

Winfield, K.A., 2003, Spatial variability of sedimentary interbed properties near the Idaho Nuclear Technology and Engineering Center at the Idaho National Environmental and Engineering Laboratory: U.S Geologcal Survey Water Resources Investigations Report 03-4142 [http://pubs.usgs.gov/wri/wri034142/]. 
Table 1 Particle size analysis statistics from Rainier Mesa soil samples using the method of moments (Beyer, 1991).

\begin{tabular}{|lllll|}
\hline Sample name & $\begin{array}{c}\text { Arithmetic } \\
\text { Mean }(\mathrm{mm})\end{array}$ & $\sigma$ & $\begin{array}{c}\text { Geometric } \\
\text { Mean (mm) }\end{array}$ & $\sigma$ \\
\hline RM1: 4 cm depth & 0.437 & 1.097 & 0.037 & 8.243 \\
RM1: 14 cm depth & 8.810 & 10.852 & 0.913 & 0.024 \\
RM2: 4 cm depth & 0.743 & 1.412 & 0.108 & 0.086 \\
RM2: 12 cm depth & 3.001 & 4.493 & 0.363 & 0.015 \\
RM4: $10 \mathrm{~cm}$ depth & 0.310 & 0.463 & 0.135 & 0.004 \\
RM4: $19 \mathrm{~cm}$ depth & 0.410 & 1.091 & 0.055 & 0.007 \\
\hline
\end{tabular}


Table 2 USDA textural class information from particle size analysis of Rainier Mesa soil samples.

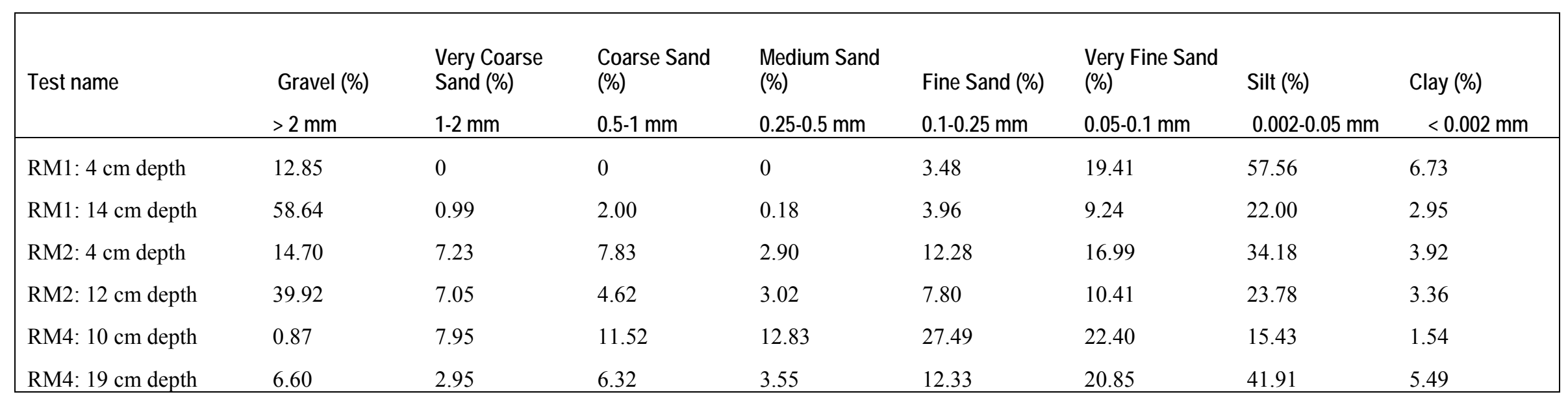


Table 3. Cumulative frequency distribution statistics, by diameter, from particle size analysis of Rainier Mesa soil samples.

\begin{tabular}{|c|c|c|c|c|c|c|c|c|c|}
\hline \multirow{2}{*}{ Test name } & \multicolumn{9}{|c|}{$\begin{array}{l}\text { Diameters at a } \\
\text { Given Cumulative } \\
\text { Frequency }(\mathbf{m m})^{1}\end{array}$} \\
\hline & d5 & d10 & d16 & d25 & d50 & d60 & d75 & d84 & d95 \\
\hline RM1: $4 \mathrm{~cm}$ depth & 0.0015 & 0.0031 & 0.0058 & 0.0116 & 0.032 & 0.044 & 0.071 & 0.102 & 3.251 \\
\hline RM1: $14 \mathrm{~cm}$ depth & 0.003 & 0.010 & 0.023 & 0.050 & 3.243 & 6.000 & 22.54 & 25.43 & 29.47 \\
\hline RM2: $4 \mathrm{~cm}$ depth & 0.003 & 0.007 & 0.014 & 0.027 & 0.080 & 0.128 & 0.851 & 1.276 & 3.895 \\
\hline RM2: $12 \mathrm{~cm}$ depth & 0.003 & 0.008 & 0.019 & 0.043 & 0.686 & 1.991 & 3.732 & 6.749 & 14.06 \\
\hline RM4: $10 \mathrm{~cm}$ depth & 0.013 & 0.031 & 0.048 & 0.067 & 0.134 & 0.188 & 0.376 & 0.651 & 1.315 \\
\hline RM4: $19 \mathrm{~cm}$ depth & 0.002 & 0.004 & 0.009 & 0.018 & 0.054 & 0.074 & 0.138 & 0.489 & 2.860 \\
\hline
\end{tabular}

${ }^{1}$ Diameters are calculated by linear interpolation of the cumulative size distribution. 
Table 4. Ponded $K_{\mathrm{fs}}$ estimates from Rainier Mesa using the Nimmo and others (2009) method.

\begin{tabular}{|c|c|c|c|c|}
\hline Test name & $\begin{array}{l}\text { Latitude }^{1} \\
\text { [DD MM SS] }\end{array}$ & $\begin{array}{l}\text { Longitude }^{1} \\
\text { [DD MM SS] }\end{array}$ & $\begin{array}{l}K_{f s} \\
{\left[\mathrm{~ms}^{-1}\right]}\end{array}$ & Material \\
\hline RM1 & $37^{\circ} 10^{\prime} 21.1^{\prime \prime}$ & $116^{\circ} 12^{\prime} 34.9^{\prime \prime}$ & $1.7 \times 10^{-5}$ & Fine, stony soil with desiccation cracks \\
\hline RM2 & $37^{\circ} 10^{\prime} 21.1^{\prime \prime}$ & $116^{\circ} 12^{\prime} 34.9^{\prime \prime}$ & $2.2 \times 10^{-5}$ & Fine, stony soil with desiccation cracks \\
\hline RM4 & $37^{\circ} 10^{\prime} 21.1^{\prime \prime}$ & $116^{\circ} 12^{\prime} 34.5^{\prime}$ & $1.2 \times 10^{-4}$ & Juniper needles and duff overlying fine soil \\
\hline $\mathrm{RM}^{2}$ & $37^{\circ} 10^{\prime} 21.1^{\prime \prime}$ & $116^{\circ} 12^{\prime} 34.5^{\prime}$, & $9.0 \times 10^{-5}$ & Juniper needles and duff overlying fine soil \\
\hline RM6 & $37^{\circ} 11^{\prime} 8.4^{\prime \prime}$ & $116^{\circ} 13^{\prime} 12.4^{\prime \prime}$ & $9.0 \times 10^{-5}$ & Coarse textured channel sediments in dry wash \\
\hline $\mathrm{RM} \mathrm{NT}^{3}$ & $37^{\circ} 11^{\prime} 50.0^{\prime}$, & $116^{\circ} 11^{\prime} 1.4^{\prime \prime}$ & $5.2 \times 10^{-5}$ & Fine sediment in vegetated area in pond bottom \\
\hline $\mathrm{RM} \mathrm{NT2}{ }^{3,4}$ & $37^{\circ} 11^{\prime} 50.0^{\prime}$, & $116^{\circ} 11^{\prime} 1.4^{\prime \prime}$ & $3.6 \times 10^{-5}$ & Fine sediment in vegetated area in pond bottom \\
\hline RM NT3 $^{3}$ & $37^{\circ} 11^{\prime} 50.6^{\prime \prime}$ & $116^{\circ} 11^{\prime} 2.1^{\prime \prime}$ & $1.6 \times 10^{-5}$ & Fine sediment in pond bottom; desiccation cracks \\
\hline
\end{tabular}

1Datum is NAD83; ${ }^{2}$ RM5 is a repeat test of RM4 at the same location; ${ }^{3}$ At $N$ tunnel drainage pond 3 (dry); ${ }^{4}$ RM NT2 is a repeat test of RM NT1 at the same location. 
Figure 1

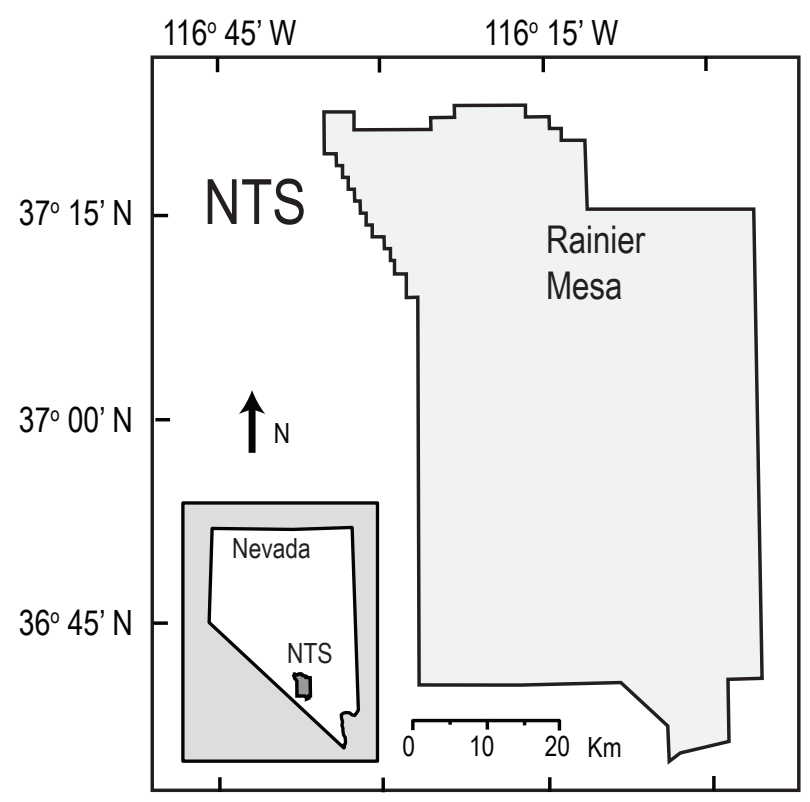

Figure 1. Map of the Nevada Test Site (NTS) showing the location of Rainier Mesa. 
Figure 2

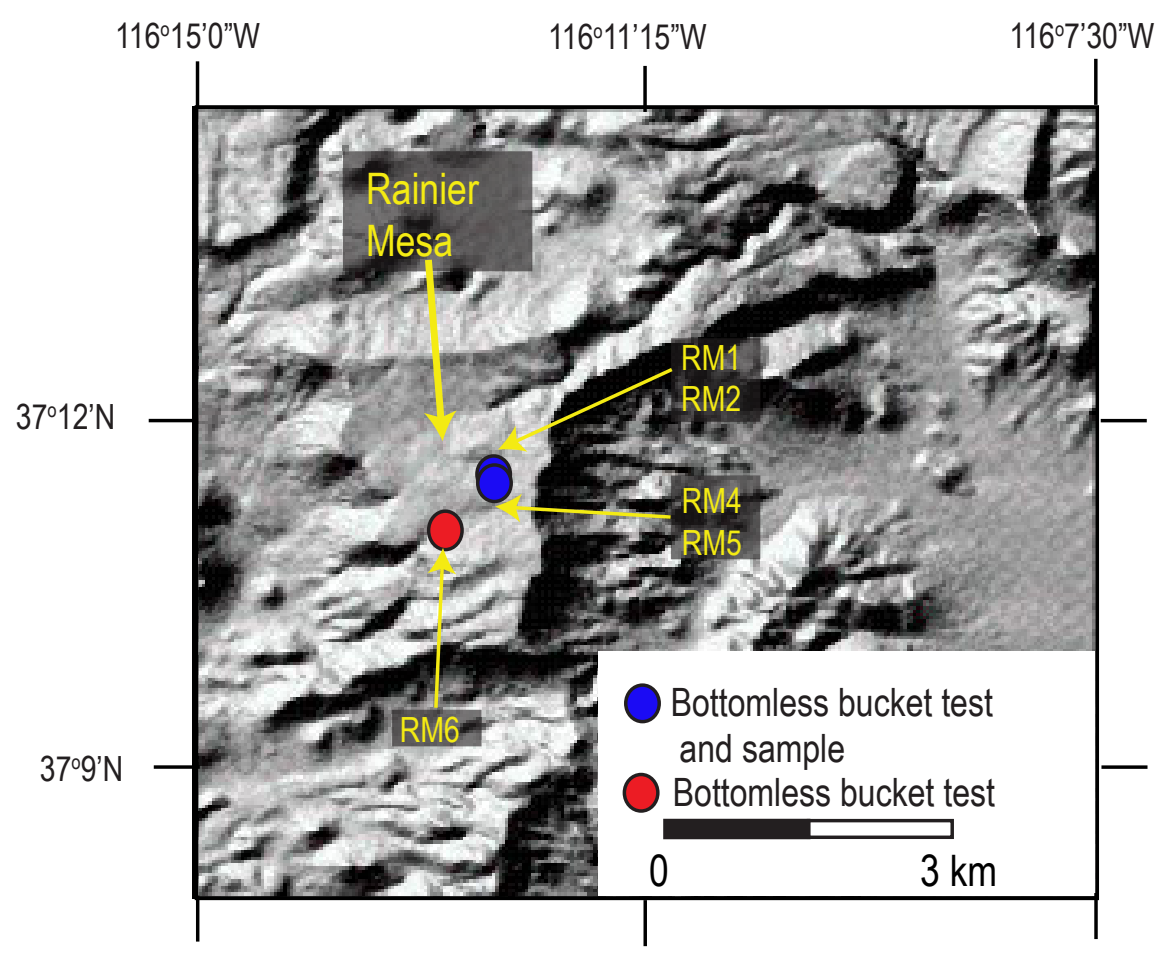

Figure 2. Shaded relief map of Rainier Mesa showing the locations of infiltration tests and soil samples. Image from the National Map Seamless Server of the U.S. Geological Survey. 
Figure 3

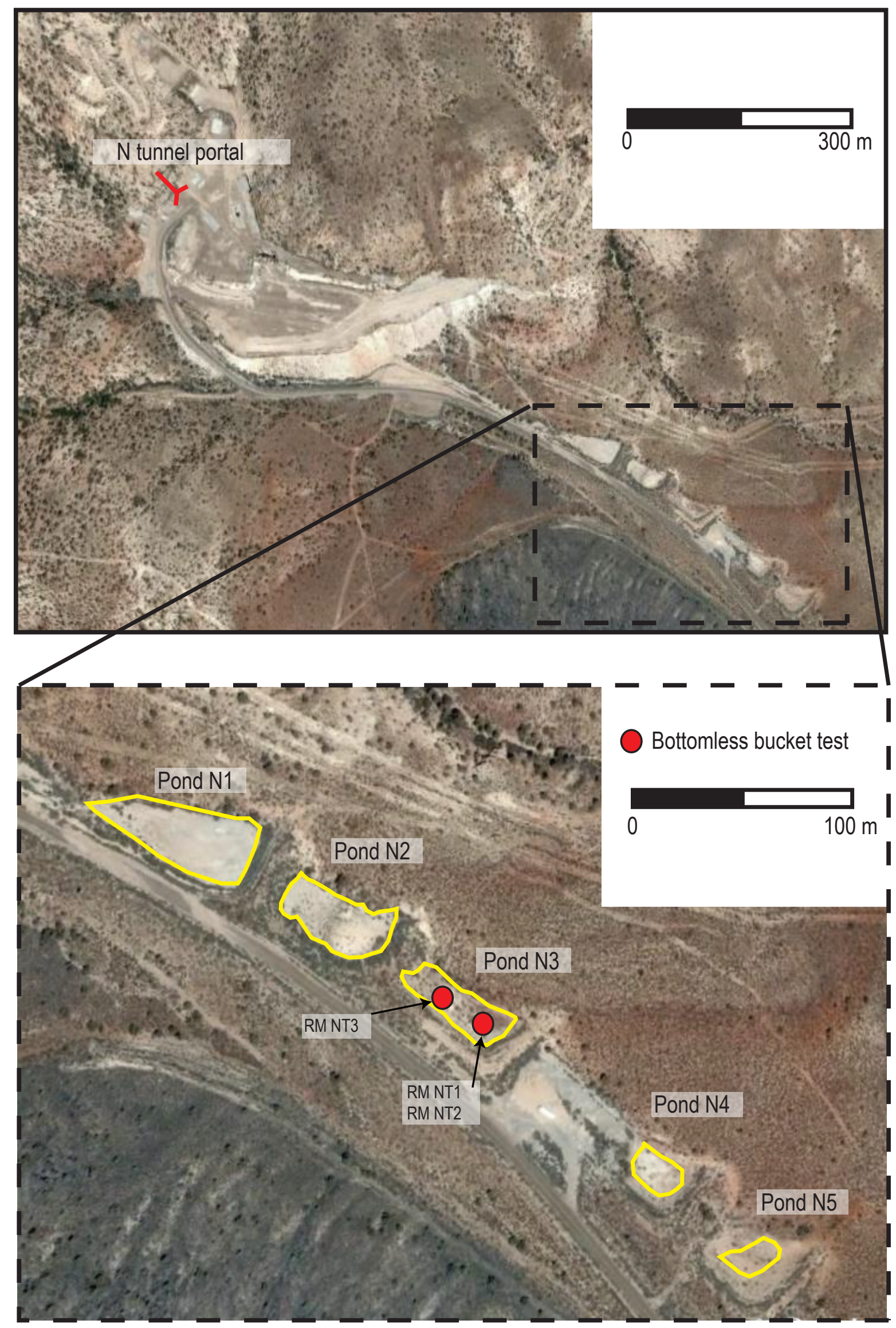

Figure 3. Satellite images of the U12n tunnel portal area and ponds at Rainier Mesa showing infiltration test locations. 
Figure 4
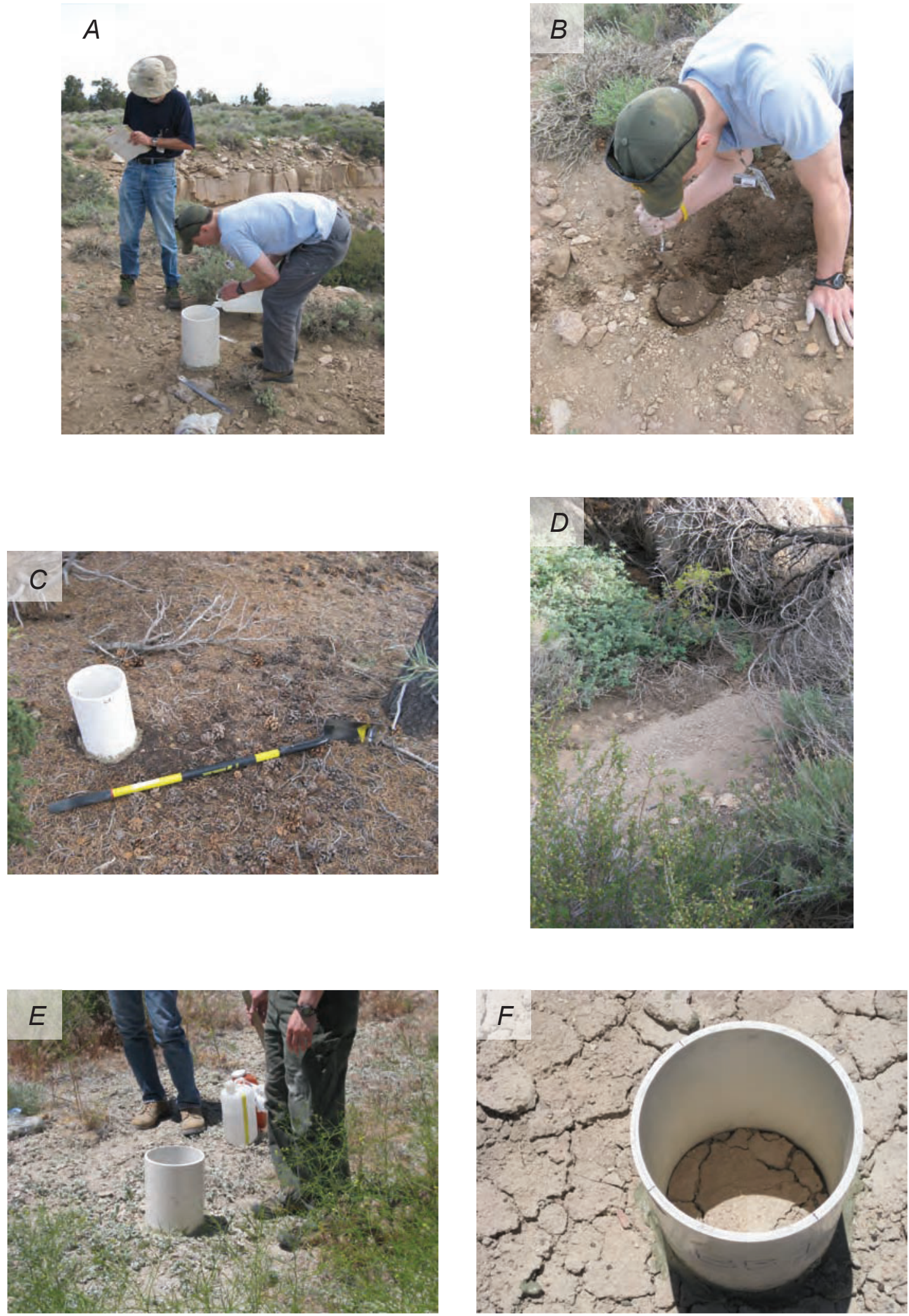

Figure 4. Photographs of measurement sites $(A) \mathrm{RM} 1,(B) \mathrm{RM} 2,(C) \mathrm{RM} 4$ and RM5, $(D)$ RM6, (E) RM NT1 and RM NT2, and $(F)$ RM NT3. 


\section{Figure 5}
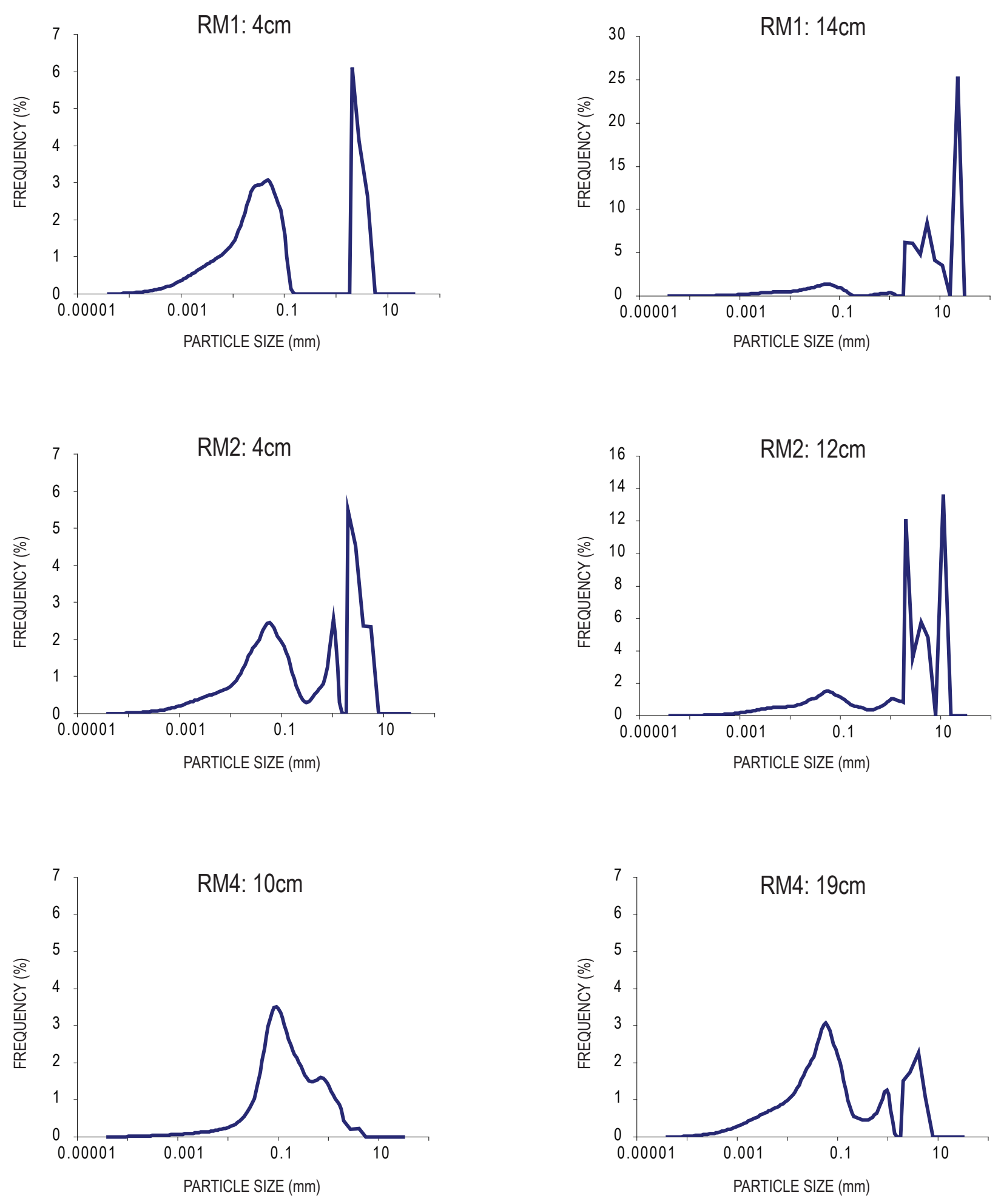

Figure 5. Probability distribution functions given in percentages based on particle size analysis of the six soil samples from Rainier Mesa. 
Figure 6

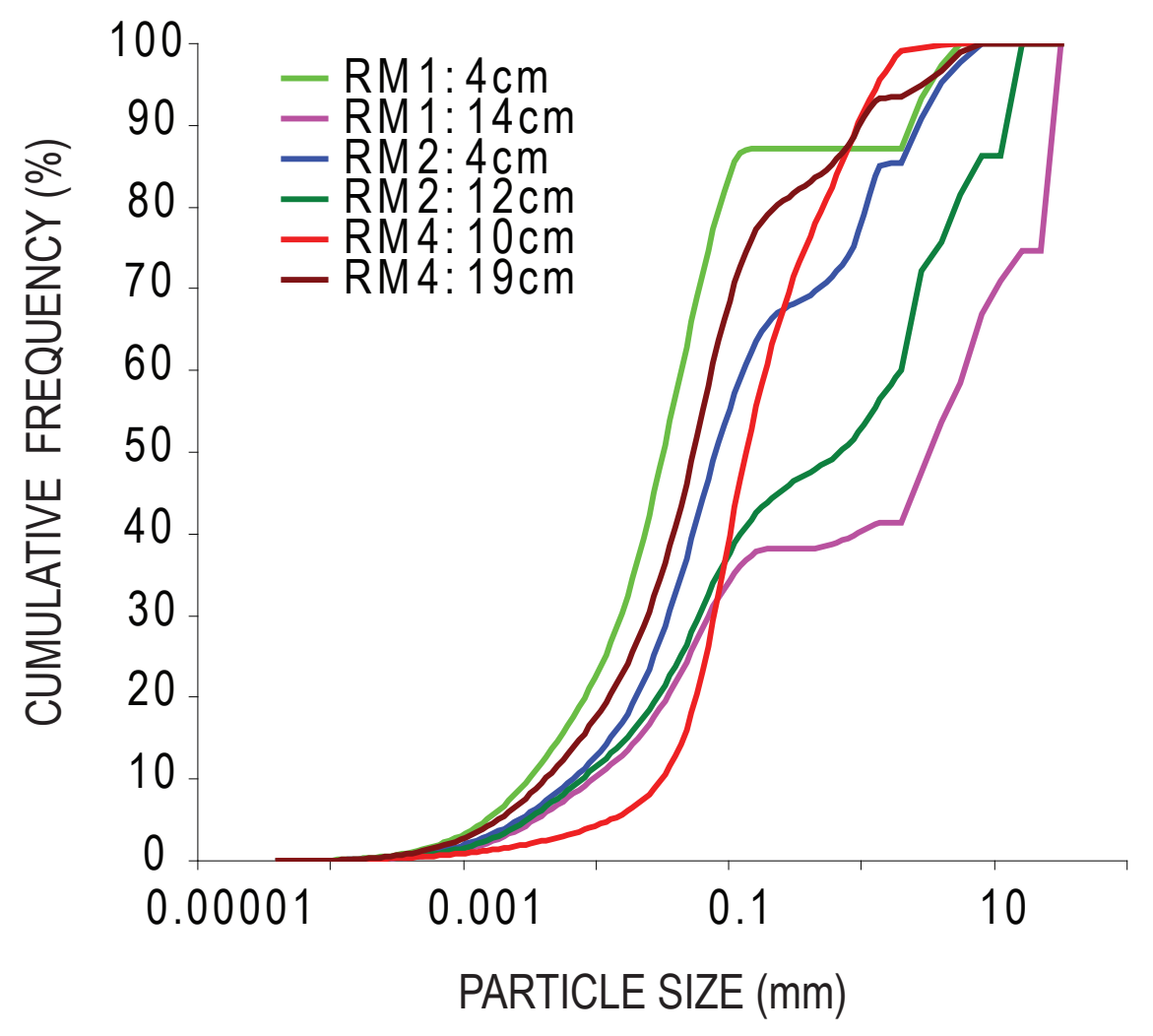

Figure 6. Cumulative distribution functions given in cumulative percentages based on particle size analysis of the six soil samples from Rainier Mesa. 